\title{
Legal Protection for Car Rental Owners
}

\author{
Denny Zahuri ${ }^{1}$, Azis Budianto ${ }^{2}$ \\ University of Borobudur ${ }^{1,2}$ \\ \{dennyunborr@gmail.com¹,azis_budianto@borobudur.ac.id²\}
}

\begin{abstract}
The paper discusses the legal protection for rental owners against car embezzlement by using a qualitative approach with a normative juridical method. Legal protection for rental owners is covered in the Criminal Code, related to embezzlement of goods. In the event of car embezzlement, the rental owner can submit a report to the relevant authorities so that it can be processed following applicable laws. Preventive and repressive measures need to be carried out on an ongoing basis, to guard against the crime of embezzling rental cars repressive efforts by conducting investigations and investigations by the police, giving severe punishments/demands to cause a deterrent effect on the perpetrators of criminal acts.
\end{abstract}

Keywords: Criminal Law; Rental; Embezzlement

\section{Introduction}

The State of Indonesia is a constitutional state as stated in the 1945 Constitution of the Republic of Indonesia (UUD 1945), which regulates all aspects of the life of the Indonesian people. This is strictly regulated in the explanation of the 1945 Constitution of the Republic of Indonesia that "The Republic of Indonesia is based on the law (rechsstaat), not based on mere power (machstaat)". The law here has a very important meaning in the aspects of life as a guideline for human behavior concerning other humans. In a rule of law, the law is used as the main basis in moving every aspect of life in society, nation, and state. Besides, the law is also used as a means of social control, so that laws exist to keep people in universally accepted patterns of behavior. In such a function, the law not only maintains what exists and is accepted in society but beyond that law can still carry out its other functions, namely by making changes in society. Law is tasked with integrating and coordinating the interests of each individual in society. So, it is expected that the interests of one another can go hand in hand and not contradict each other. To achieve this goal can be done by limiting and protecting these interests [1].

Transportation is a means of moving people or goods from one place to another by using a vehicle that is moved by humans or machines. Transportation itself is divided into several types, seen from the place such as land, sea, and air transportation, seen from the type of both public and private transportation. City transport cars and buses are considered as alternative driving options at low cost but have several disadvantages such as a lower level of comfort and safety, therefore many people are more interested in owning a private car. But not all people can afford to buy private cars for various reasons such as the high price of cars, the high maintenance costs of these four-wheeled vehicles, the price of fuel oil such as gasoline or 
diesel which continues to increase every year. The inability of some people to buy private cars is what entrepreneurs see as a big business opportunity, namely by opening a car rental business.

Car rental is a type of business that provides car rental services based on an agreement between the tenant and the car owner, where the car can be rented daily or according to the contract, and in that agreement, some terms and conditions are binding for both parties. The car rental business is considered to have a large enough opportunity with quite a large profit. Most of the reasons, customers rent a rental car, such as wanting to travel somewhere but do not have a vehicle, and a rental car is their choice.

Many cases of embezzlement of rental cars are usually caused because it is easy for someone to be able to rent a car only with the requirements that are classified as easy to fulfill, such as photocopies of KTP (Identity Cards), photocopies of SIM (driving licenses), photocopies of family cards and photocopies NPWP (Taxpayer Identification Number) [2]. The incidence of criminal acts committed by the lessee against the rental property of the rental owner is due to abuse of rights or abuse of trust where the crime of embezzlement is regulated in the provisions of Article 372 of the Criminal Code (KUHP). An embezzlement is an act of taking the property of another person partly or wholly where the control of the item already belongs to the perpetrator, but the control occurs legally. For example, control of an item by a perpetrator occurs because the owner entrusts the goods, or control of the goods by the perpetrator occurs because of his job or position, for example, a custody officer. The purpose of embezzlement is to have goods or money in his control where the goods/money belong to someone else. In the case of embezzlement of the rental car, the owner and the tenant have come face to face, have known each other's identities, but when in the middle of the agreement the tenant deliberately runs away, sells, or transfers the rental car to a third party.

Crime in society develops along with the development of society itself because crime is a product of society and this needs to be tackled [3]. This is because crimes cannot disappear by themselves, on the other hand, criminal cases are becoming more frequent and the most dominant is the type of crime against assets, especially embezzlement. "That crimes against the property will appear to be increasing in developing countries. This increase is in line with economic development and growth."

Crime can be interpreted criminologically and juridically. Crime in a criminological sense is human action that tarnishes the basic norms of society. This is intended as an act of elements that violate the rules that live and develop in society. Juridical crime, namely evil behavior or evil deeds in the meaning of criminal law, means that the crime is formulated in the criminal regulations. Another word for this crime is a criminal act/crime/offense. This paper intends to further examine the legal protection for car rental business owners from the crime of car embezzlement.

\section{Methodology}

A qualitative approach with the normative juridical method [4] will be used in this study to analyze the main problems related to the study of legal protection for car rental business owners against embezzlement of goods. Data collection is carried out by using applicable statutory documents, as well as literature related to the main problem at hand. The prescriptive analysis is used to be able to present data comprehensively and thoroughly [5]. 


\section{Result and Discussion}

Based on Article 1548 of the Civil Code, it is stated that the meaning of leasing is an agreement whereby one party binds himself to provide the enjoyment of an item to another party for a certain period, with the payment of a price that the party has agreed to last. People can rent out various types of goods, both fixed and movable. According to Algra, leasing is an agreement for the temporary use of an object, both movable and immovable, with the payment of a certain price [6].

In a criminal act, knowing the criminal act that has occurred is a must. Some of the criminal acts that occur must be known for their meaning and definition, including the crime of embezzlement. Embezzlement means having goods or things that are owned by other people but the act is not a crime. In Article 372 of the Criminal Code (KUHP) it states: Anyone who deliberately violates the law owns something or the whole or part of it belongs to another person, but who is in his power not because the crime is threatened due to embezzlement, with a maximum sentence of four years or a maximum fine of nine hundred rupiahs. Tongat explained his explanation regarding the criminal act of embezzlement, namely [7]: Criminal acts as mentioned in CHAPTER XXIV of the Criminal Code are more accurately described as "crimes of abuse of rights" or "abuse of trust". This is because the essence of the criminal acts regulated in CHAPTER XXIV of the Criminal Code is "abuse of rights" or "abuse of trust". Because with this mention, it will be easier for everyone to know what actions are prohibited and punishable under these provisions. Furthermore, Tongat emphasizes the meaning of embezzlement, that: If an object is in the possession of a person not because of a criminal act, but because of a legitimate act, for example, due to storage, an agreement for safekeeping of goods, and so on, then the person who is entrusted with saving and so on that. Elements of the Crime of Embezzlement The elements of the Crime of Embezzlement According to Tongat that based on the provisions of Article 372 of the Criminal Code, a criminal act in its main form has the following elements [7] :

a. Objective Elements consist:

1. Claimed as one's own

2. Something goods

3. Whole or part of it is the property of another person

4. Who is in his power not because of crime

b. Subjective Elements

1. The Element of Intention

2. Elements Against the Law

When it comes to theft, sufficient discussion has been made of this element of being against the law. Therefore, here it will not be discussed again. Concerning deliberate action, it is important to know that the intentionality of the perpetrator must also be directed at this element against the law, the meaning of which has been explained above. There are several differences between embezzlement and theft. The differences include:

a. About his material actions. Embezzlement is about the act of possessing, whereas theft is the act of taking. In theft, there is an element of belonging, which is a subjective element. In embezzlement, the element of having is an element of behavior, in the form of an objective element. Completion of embezzlement requires completion or realization of the act of possessing, while

b. Regarding the existence of the object of crime in the hands of the perpetrator. In theft, the object is in the hands/power of the perpetrator as a result of taking action, meaning that the 
object is under his control because of a crime (theft). But not in embezzlement, the object is under his control because of his actions according to the law.

Types of Crime of Embezzlement The criminal act of embezzlement in the Criminal Code consists of several forms, namely [8]:

a. The criminal act of embezzlement in the form of principal or ordinary embezzlement

b. Light darkening

c. Weighting with weighting; and

d. Embezzlement in the family

Ordinary embezzlement or what is also known as embezzlement in essence, namely, embezzlement, the provisions of which are regulated in Article 372 of the Criminal Code which states that: Anyone who deliberately violates the law owns something or wholly or partly belongs to another person, but that which is in his power is not due to a crime threatened with embezzlement, with a maximum sentence of four years or a maximum fine of nine hundred rupiahs [9]. In the criminal case of embezzlement of a rental car, several factors cause the perpetrators to commit this act. The factors are:

a. Economic factors. The economy is the main factor that causes the perpetrator committed the crime of embezzlement of the rental's four-wheeled motorized vehicle. The high need for clothing and food, large debts, social competition, and a lifestyle are among the triggers for the evil intentions of the perpetrators to commit these crimes. Almost every year the price of necessities continues to increase, while the income of each individual is not necessarily able to meet this increase. So that this results in an excuse for someone to commit a criminal act of embezzling a rental car.

b. The factor does not know the legal consequences. There is still a lack of legal awareness, so there is a big possibility for criminal acts to occur, especially the embezzlement of rental cars. Rental car owners are less aware of the threat of embezzlement, and the embezzlers' lack of fear of legal threats makes them dare to commit embezzlement.

c. The opportunity utilization factor. The opportunity factor referred to is the opportunity that arises from a gap and also situations that allow a person (the perpetrator) to commit the crime of embezzlement.

d. Do not use a driver or key-off system. Car hire uses a key-release system. The key release that is meant here is when the car is rented without the driver provided by the rental party so that it becomes a great opportunity for the criminal to embezzle the car being rented.

e. The Weak Factor of the Rental Security System. Even though rental owners have made preventive efforts by installing a vehicle tracking system on the vehicle they rented so that they can easily track the whereabouts of the vehicle being rented, not all rentals use it considering the costs required to install the system on all their vehicle fleets will cost a lot of money.

Preventive efforts are made to overcome the embezzlement of four-wheeled motorized vehicles belonging to a rental by making a contract agreement which points out the rental regulations that are more profitable for car rental business service providers carried out by the owner of the rental car company as well as conducting patrols. directed and regularly towards motorized vehicles and their documents to ensure that the vehicle is not a vehicle obtained from the proceeds of a criminal act, especially theft and embezzlement and conducts sustainable legal counseling, both to the public and every owner of a rental car business to be more careful -Be careful and tighten rental procedures to reduce the crime rate of embezzlement against rental cars by the police, and repressive efforts by carrying out investigations and investigations by the police, giving punishment/demands that are serious to cause a deterrent effect on the perpetrators of the criminal act of embezzlement. 


\section{Conclusion}

Legal protection for rental owners is covered in the Criminal Code, related to embezzlement of goods. In the event of car embezzlement, the rental owner can submit a report to the relevant authorities so that it can be processed under applicable laws. Preventive and repressive measures need to be carried out on an ongoing basis, to guard against the crime of embezzling rental cars. Repressive efforts by conducting investigations and investigations by the police, giving severe punishments/demands to cause a deterrent effect on the perpetrators of criminal acts.

\section{References}

[1] P. A. F. Lamintang, Basics of Indonesian Criminal Law. Bandung: Cipta Aditya Bakti, 2011.

[2] Kurniawan, "Police Unload Rental Car Embezzlement Syndicate," Tempo, 2020. www.tempo.com/news/regional (accessed Mar. 01, 2020).

[3] B. Waluya, Sociology: Dive into Social Phenomena in Society, 1st ed. Bandung: PT Setia Purna Inves, 2007.

[4] I. M. P. Diantha, "Normative Legal Research Methodology," Teor. Metodol. Penelit. a., 2017.

[5] J. Ibrahim, "Normative Law Theory and Research Methods," Bayu Media, Malang, 2006.

[6] N. E. Algra, Beginning of Law. Bandung: Bina Cipta, 2015.

[7] Tongat, Material Criminal Law. Malang: UMM Press, 2006.

[8] Muladi and B. N. Arief, Criminal Law Theories and Policies. Bandung: Alumni, 2005.

[9] T. Andrisman, Principles and Basic Rules of Indonesian Criminal Law. Bandar Lampung: Unila, 2009. 